\title{
Milligram per Liter Fibrinogen Equivalent Units
}

National Cancer Institute

\section{Source}

National Cancer Institute. Milligram per Liter Fibrinogen Equivalent Units. NCI Thesaurus.

Code C158291.

A unit of equivalent concentration equal to the number of milligrams of fibrinogen per unit volume equal to one liter. 